\title{
Status of Sesame Diseases Grown in Different Agroclimatic Zones of Odisha
}

\author{
B. Khamari ${ }^{1 *}$, S.K. Beura ${ }^{2}$ and N. Ranasingh $^{3}$ \\ ${ }^{1}$ Department of Plant Pathology, IAS, SoA, Bhubaneswar, Odisha, India \\ ${ }^{2}$ Department of Plant Pathology, CA, OUAT, Bhubaneswar, Odisha, India \\ ${ }^{3}$ College of Agriculture, OUAT, Bhawanipatna, Odisha, India \\ *Corresponding author
}

\section{A B S T R A C T}

\begin{tabular}{|l|}
\hline Ke y w or d s \\
Agroclimatic zones, \\
Odisha, Sesame and \\
Survey
\end{tabular}

An intensive survey was conducted at flowering to ripening of capsule to record the incidence of charcoal rot in ten agroclimatic zones of Odisha during rabi 2014-15. Almost all the fields were infected by more than one disease. The major diseases of sesame recorded were Macrophomina stem and root rot, Cercospora leaf spot, Alternaria blight, powdery mildew, phytopthora blight and phyllody to some extent. Incidence of foliar diseases such as Alternaria blight, Powdery mildew, Cercospora leaf spot ranged from grade 2-4, 0-3 and 1-2 respectively with maximum incidence at Balianta. Phyllody, a phytoplasma disease was also seen in many fields ranging from $0-2.3 \%$. Phytopthora blight was observed in some patches. Fusarium wilt recorded $0.5-9.78 \%$ with highest incidence at Bheden. Macrophomina stem and root rot was found in all the fields surveyed ranging from 8.0-23.8\% with highest incidence at Balianta and lowest at Agarpada.

\section{Introduction}

Sesame (Sesamum indicum L.) is an important edible oilseed crop which is valued as quality food, nutrition, edible oil, bio-medicine and health care, all in one. It is mostly grown in hotter and drier areas of tropical and subtropical regions. Around 60-65 countries of the world produce sesame seed. China, India, Sudan, Myanmar, Uganda, Nigeria, Bangladesh, Pakistan, Tanzania, Mexico, Thailand and Egypt are major producer of sesame. India is the world leader with the maximum $(25.8 \%)$ production from the largest $(29.8 \%)$ area and highest $(40 \%)$ export in the world. India produces 870 thousand metric tons in fiscal year 2015-2016. Sesame is largely cultivated in the western, southern and eastern parts of with productivity of $413 \mathrm{~kg} / \mathrm{ha}$ India (Annual report, 2016-17, Department of Agriculture, Cooperation \& Farmers Welfare Ministry of Agriculture \& Farmers Welfare Government of India). In Odisha, it is generally grown in all most all districts, mainly in Ganjam, Angul, Sundergarh, Dhenkanal, Raygada, Subarnapur, Bargarh and Bolangir. Being a drought-tolerant, short duration crop, it is adapted to many cropping system. There is a large yield gap and farm loss exists in sesame crop because of knowledge gap, poor crop management practices and disease pest infestation. In Odisha, sesame is generally grown in rainfed condition in uplands, poor light textured soil 
during rabi and summer season. Out of all these constraints, disease prevalence is most important. To critically investigate the disease prevalence, this survey work was carried out in ten agroclimatic zones of Odisha.

\section{Materials and Methods}

A survey work was undertaken in ten agroclimatic zones of Odisha, during rabi, 2014-15 at flowering stage to pod formation stage and detail information regarding crop history, crop stage, variety grown, soil type, soil $\mathrm{P}^{\mathrm{H}}$ were recorded. The foliar diseases such as alternaria leaf spot, cercospora leaf spot and powdery mildew were recorded in scale. In each plot 10 random plants were selected and all the leaves were scored for the severity of Cercospora leaf spot, alternaria leaf spot and powdery mildew by using 0-5 scale. Incidence of fusarium wilt and Macrophomina stem and root rot were expressed in percentage. The per cent disease incidence was calculated as follows

$$
\mathrm{PDI}=\frac{\text { Total number of infected plants }}{\text { Total number of plants in the plot }} \times 100
$$

\section{Results and Discussion}

During the survey work different diseases were recorded from different fields (Table 1). Almost all the fields were affected by more than one disease. None of the field withnessed healthy crop. Among the foliar diseases, Alternaria blight, Cercospora leaf spot, powdery mildew, phytopthora blight were serious disease. Phyllody was also reported from some areas. Incidence of Alternaria was very common and seen in almost all the field surveyed. It ranged from grade 2-4 with maximum incidence at Balianta (Table 2). Powdery mildew another important disease occurred in a range of grade 0-3 with highest incidence at Balianta causing huge loss in field. Cercospora leaf spot also seen in all the fields surveyed during the period ranging from grade 1-2. Phyllody, a phytoplasma disease was also observed in some fields ranging from 0-2.3\%. Phytopthora blight was also observed in some patches. Among the soil borne disease, Fusarium wilt and macrophomina stem and root rot is very important. Fusarium wilt was recorded highest at Bheden with disease incidence of $9.78 \%$ followed by Balianta $(8.0 \%)$ with lowest incidence at Betanati $(0.5 \%)$.

Macrophomina stem and root rot which is an emerging disease was recorded in almost all the fields surveyed causing huge economic loss. It is a serious disease of sesame in Odish ranging from $8.0-23.8 \%$ with average incidence of $15.34 \%$. The highest macrophomina incidence was observed at Balianta (23.8\%) followed by Bhawanipatna (19.2\%) and lowest at Agarpada (8.0\%).

Similar finding were also given by earlier workers. Maiti et al., (1985) stated sesamum phyllody is the most destructive disease in India. He also stated Leaf curl is also responsible for heavy losses when it infects at early growth stages of the crop. Bacterial leaf spot, Pseudomonas sesami causes considerable yield reduction whenever it infects the sesamum crop. Bacterial blight, Xanthomonas sesami is serious during the monsoon and to young plants. $\mathrm{He}$ also reported among the fungal diseases, leaf blight (Alternaria sesami), leaf spot (Cercospora sp.) and leaf blight (Phytophthora parasitica) are important. Charcoal rot, Macromophomina phaseolina is a widespread and destructive disease and it is difficult to control. Mildew is not a serious disease (Maiti et al., 1985). Ransingh and Samal (2013) found low productivity of sesame in Odisha due to major fungal diseases like wilt caused by Macrophomina sp. and Fusarium sp., leaf spot disease caused by Alternaria $s p$. and Cercospora sp. as well as Phyllody and insect attack by capsule borer and hawk moth. 
Table.1 Survey of sesame fields under different agroclimatic zones

\begin{tabular}{|c|c|c|c|c|c|}
\hline $\begin{array}{l}\text { Sl. } \\
\text { No. }\end{array}$ & $\begin{array}{l}\text { Place of } \\
\text { survey }\end{array}$ & Agroclimatic zones & $\begin{array}{l}\text { Soil } \\
\text { texture }\end{array}$ & $\mathrm{pH}$ & Crop history \\
\hline 1 & Bheden & $\begin{array}{l}\text { Western Central } \\
\text { Table Land }\end{array}$ & Loamy & 6.3 & Paddy -sesame- paddy \\
\hline 2 & Balianta & $\begin{array}{l}\text { East \& South } \\
\text { Eastern Coastal } \\
\text { Plain }\end{array}$ & Sandy loam & 6.02 & Sesame -sesame-sesame \\
\hline 3 & Nuagaon & $\begin{array}{l}\text { Mid Central Table } \\
\text { Land }\end{array}$ & $\begin{array}{l}\text { Loamy } \\
\text { sand }\end{array}$ & 6.9 & $\begin{array}{l}\text { Paddy -vegetable- } \\
\text { sesame }\end{array}$ \\
\hline 4 & Papadahandi & $\begin{array}{l}\text { Eastern Ghat High } \\
\text { Land }\end{array}$ & Sandy clay & 6.41 & Paddy -maize-sesame \\
\hline 5 & Betanati & $\begin{array}{l}\text { North Central } \\
\text { Plateau }\end{array}$ & Sandy loam & 6.27 & Paddy -maize- sesame \\
\hline 6 & Kalimela & South Eastern Ghat & Loam & 6.8 & Paddy - sesame-paddy \\
\hline 7 & Agarpada & $\begin{array}{l}\text { North Eastern } \\
\text { Coastal Plain }\end{array}$ & Clay loam & 6.9 & Paddy -paddy- sesame \\
\hline 8 & Kirei & $\begin{array}{l}\text { North Western } \\
\text { Plateau }\end{array}$ & $\begin{array}{l}\text { Loamy } \\
\text { sand }\end{array}$ & 6.5 & Paddy-vegetable-sesame \\
\hline 9 & Khajuripada & North Eastern Ghat & Loamy & 6.4 & $\begin{array}{l}\text { Paddy- vegetable- } \\
\text { sesame }\end{array}$ \\
\hline 10 & Bhawanipatna & $\begin{array}{l}\text { Western Undulating } \\
\text { Zone }\end{array}$ & Clay loam & 6.8 & Paddy -sesame-paddy \\
\hline
\end{tabular}

Table.2 Disease incidence of sesame in different zones

\begin{tabular}{|c|l|l|c|c|c|c|c|c|}
$\begin{array}{c}\text { SI. } \\
\text { No. }\end{array}$ & Place & $\begin{array}{c}\text { Mac } \\
(\%)\end{array}$ & $\begin{array}{c}\text { Fus } \\
(\%)\end{array}$ & $\begin{array}{c}\text { Alt } \\
\text { (Grade) }\end{array}$ & $\begin{array}{c}\text { PM } \\
\text { (Grade) }\end{array}$ & $\begin{array}{c}\text { Cer } \\
\text { (Grade) }\end{array}$ & $\begin{array}{c}\text { Phy } \\
(\%)\end{array}$ \\
\hline $\mathbf{1}$ & Bheden & Bheden local & 18.09 & 9.78 & 3 & 0 & 2 & 0 \\
\hline $\mathbf{2}$ & Balianta & VRI-1 & 23.8 & 8.0 & 4 & 3 & 2 & 2.3 \\
\hline $\mathbf{3}$ & Nuagaon & Nuagaon local & 12.8 & 3.0 & 3 & 0 & 2 & 0.6 \\
\hline $\mathbf{4}$ & Papadahandi & $\begin{array}{l}\text { Papdahandi } \\
\text { local }\end{array}$ & 15.2 & 4.1 & 2 & 0 & 2 & 1.0 \\
\hline $\mathbf{5}$ & Betanati & Betanati local & 18.8 & 0.5 & 2 & 2 & 1 & 0 \\
\hline $\mathbf{6}$ & Kalimela & Kalimela local & 11.3 & 0.8 & 3 & 1 & 2 & 0.8 \\
\hline $\mathbf{7}$ & Agarpada & Agarpada local & 8.0 & 1.0 & 3 & 1 & 1 & 0.6 \\
\hline $\mathbf{8}$ & Kirei & $\begin{array}{l}\text { Sundergarh } \\
\text { local }\end{array}$ & 15.8 & 3.9 & 2 & 0 & 1 & 1.4 \\
\hline $\mathbf{9}$ & Khajuripada & Phulbani local & 10.5 & 2.9 & 3 & 3 & 1 & 0.0 \\
\hline $\mathbf{1 0}$ & Bhawanipatna & Narla local & 19.2 & 4.8 & 4 & 0 & 2 & 1.4 \\
\hline
\end{tabular}

Mac $=$ Macrophomina, Fus $=$ Fusarium, Alt $=$ Alternaria, $\mathrm{PM}=$ Powdery Mildew, Cer $=$ Cercospora, Phy $=$ Phyllody 
Sahani and Mahapatra (2014) reported Alternaria leafspot is an important disease of sesame in Odisha causing huge economic loss. Macrophomina stem rot has a vast geographical distribution and is especially problematic in tropical and subtropical countries with arid to semi-arid climates in Africa, Asia, Europe and North and South America (Gray et al., 1990; Abawi and Pastor-Corrales, 1990; Diourte et al., 1995 and Wrather et al., 2001). Reports of these workers are in the line of support to the present findings.

Survey for disease in different agroclimatic zones is a preliminary work to know the prevalence of the disease. Futher studies should be done to correlate the influence of weather conditions, soil types, cropping system as well as variety grown which will be beneficial for formulation of Integrated Disease Management module for proper management of the disease.

\section{References}

Abawi, G.S. and Corrales, M.A.P., 1990. Root rots of beans in Latin America and Africa: Diagnosis, Research Methodologies and Management Strategies. CIAT, Cali, Colombia.
Annual report, 2016-17, Department of Agriculture, Cooperation \& Farmers Welfare Ministry of Agriculture \& Farmers Welfare Government of India.

Diourte, M., Starr, J.L., Jeger, M.J., Stack, J.P. and Rosenow, D.T. 1995. Charcoal rot (Macrophomina phaseolina) resistance and the effects of stress on disease development in sorghum. $\mathrm{Pl}$. Pathol., 44: 196-202.

Gray, F.A., Kolp, B.J. and Mohamed, M.A. 1990. A disease survey of crops grown in the Bay Region of Somalia, East Africa. FAO Plant Prot Bult, 38: 39-47.

Maiti, S., Raoof, M. A., Sastry, K. S. \& Yadava, T. P. 1985. A review of sesamum diseases in India. Tropical pest management, 31(4)

Ransingh, N. and Samal, T. 2013. Sesamum in Odisha and Its Disease Pest Management. Odisha review: 78-79.

Sahani, P. and Mahapatra, S. S., 2014. Chemical management of Alternaria leaf spot disease of sesame in Odisha. Journal of Plant Protection and Environment.11(2): 64-66.

Wrather, J. A. and Koenning, S. R. 2006. Estimates of disease effects on soybean yields in the United States 2003-2005. Journal Nematol, 38: 173 - 180.

\section{How to cite this article:}

Khamari, B., S.K. Beura and Ranasingh, N. 2018. Status of Sesame Diseases Grown in Different Agroclimatic Zones of Odisha. Int.J.Curr.Microbiol.App.Sci. 7(11): 945-948. doi: https://doi.org/10.20546/ijcmas.2018.711.110 